\title{
PENGARUH INDEKS DOW JONES, NIKKEI 225, KOSPI, DAN SHANGHAI COMPOSITE INDEX TERHADAP INDEKS HARGA SAHAM GABUNGAN BURSA EFEK INDONESIA PERIODE TAHUN 2004 -2008
}

\author{
Tita Deitiana ${ }^{1}$; Stella ${ }^{2}$ \\ ${ }^{1,2}$ Trisakti School of Management \\ Jln. Kyai Tapa No. 20 Grogol, Jakarta 11440 \\ tita@stietrisakti.ac.id, stella@stietrisakti.ac.id
}

\begin{abstract}
The Jakarta Composite Index has been positively growing for last six years. As we know, the globalization is already happening in the financial sector and strong relationships have developed between the global stock markets all around the world. This research was intended to know and analyze the simultaneous and partial effect of the global stock index to Jakarta Composite Index. The Global Stock Index is represented by four regional indexes, namely Dow Jones, Nikkei 225, KOSPI, and Shanghai Composite Index. The research method used is multiple regression analysis used to find out the effect of independent variables to dependent variable. The data was the weekly closing price of Dow Jones, Nikkei 225, KOSPI, and Shanghai Composite Index as independent variables and the Jakarta Composite Index as a dependent variable from year 2004 to 2008. Results indicate that simultaneously and partially the Dow Jones, Nikkei 225, KOSPI, and Shanghai Composite Index affected the Jakarta composite index. This result shows that recently the movement of the Jakarta Composite Index is being influenced by the movement of global stock index.
\end{abstract}

Keywords: Jakarta Composite Index, Dow Jones Index, Nikkei 225 Index, KOSPI Index, Shanghai Composite Index

\begin{abstract}
ABSTRAK
Jakarta Indeks Harga Saham Gabungan positif yang berkembang untuk enam tahun terakhir. Seperti kita ketahui, globalisasi telah terjadi pada sektor keuangan dan menyebabkan hubungan yang kuat antara pasar saham global di seluruh dunia. Penelitian ini bertujuan untuk mengetahui dan menganalisis pengaruh secara simultan dan parsial dari indeks saham global ke Jakarta Composite Index. Indeks Saham Global diwakili oleh empat indeks regional, yaitu Dow Jones, NIKKEI 225, KOSPI, dan Shanghai Composite Indeks. Metode penelitian yang digunakan adalah analisis regresi berganda untuk mengetahui pengaruh variabel independen terhadap variabel dependen. Data yang digunakan adalah harga penutupan mingguan Dow Jones, Nikkei 225, KOSPI, dan Shanghai Composite Indeks sebagai variabel independen dan IHSG sebagai variabel dependen dari tahun 2004 ke 2008. Hasil penelitian menunjukkan bahwa secara simultan dan parsial Dow Jones, NIKKEI 225, KOSPI, dan Shanghai Composite Index mempengaruhi IHSG. Hal ini menunjukkan bahwa belakanganini pergerakan IHSG dipengaruhi oleh pergerakan indeks saham global.
\end{abstract}

Kata kunci: Indeks Harga Saham Gabungan, Indeks Dow Jones, Indeks Nikkei 225, Indeks KOSPI, Indeks Komposit Shanghai 


\section{PENDAHULUAN}

Pergerakan indeks saham di suatu negara sudah tentu tidak terlepas dari kondisi perekonomian negara itu secara makro. Selain itu, indeks saham juga bergerak mengikuti optimisme dan pesimisme para investor saham. Untuk Indonesia dan beberapa bursa saham yang kapitalisasi pasarnya relatif kecil, optimisme dan pesimisme para investor saham asing diduga sangat menentukan pergerakan indeks sahamnya. Rontoknya bursa-bursa global bisa menjadi sentimen negatif pada pergerakan Indeks Harga Saham Gabungan (IHSG). Investor melihat pasar saham global dunia masih belum berada kondisi yang stabil, apalagi lembaga pemeringkat Standard \& Poor's kemarin baru saja menurunkan outlook atas peringkat Inggris dari 'stabil' ke 'negatif'. Penurunan outlook itu bisa berimplikasi pada penurunan peringkat 'AAA' Inggris.

IHSG di Bursa Efek Indonesia (BEI) hari ini masih mengacu pergerakan bursa global maupun regional. Sementara itu, dalam era globalisasi dengan batas antar negara yang semakin tidak jelas membuat indeks bursa saham antarnegara saling terkait, karenanya IHSG juga sangat dipengaruhi Indeks Dow Jones dan indeks regional lainnya. Pasar modal Indonesia melalui BEI merupakan bagian tak terpisahkan dari kegiatan bursa saham global.

Penelitian yang dilakukan oleh Moh.Mansur (2005) menyatakan bahwa bagi investor yang akan melakukan transaksi investasi portofolio di Bursa Efek Indonesia, sebaiknya memperhatikan kondisi bursa saham di negara lain karena pergerakan yang terjadi di BEI tersebut dipengaruhi oleh pergerakan bursa global. Berdasarkan uraian di atas, penelitian ini dilakukan dengan tujuan untuk mengetahui, baik simultan maupun parsial besarnya pengaruh indeks harga saham bursa global, yang terdiri dari Indeks Dow Jones, Nikkei 225, KOSPI, dan Shanghai Composite (SSE) terhadap IHSG di Bursa Efek Indonesia. Penelitian ini dilakukan dengan berdasarkan pada perumusan masalah sebagai berikut (1) Bagaimanakah pengaruh Indeks Dow Jones terhadap IHSG di BEI, (2) Bagaimanakah pengaruh Indeks Nikkei 225 terhadap IHSG di BEI, (3) Bagaimanakah pengaruh Indeks KOSPI terhadap IHSG di BEI, dan (4) Bagaimanakah pengaruh Indeks SSE terhadap IHSG di BEI.

Saham dapat didefinisikan sebagai tanda penyertaan atau kepemilikan seseorang atau badan dalam suatu perusahaan atau perseroan terbatas. Wujud saham adalah selembar kertas yang menerangkan bahwa pemilik kertas tersebut adalah pemilik perusahaan yang menerbitkan surat berharga tersebut. Porsi kepemilikan ditentukan oleh seberapa besar penyertaan yang ditanamkan di perusahaan tersebut (Darmadji dan Fakhruddin, 2001: 5).

Pada saat resesi ekonomi, harga saham ini tetap tinggi, di mana emitennya mampu memberikan dividen yang tinggi sebagai akibat dari kemampuan emiten dalam memperoleh penghasilan yang tinggi pada masa resesi. Jenis saham terbaru yang diperdagangkan di BEI adalah Exchange Trade Fund (ETF), yaitu gabungan reksadana terbuka dengan saham dan pembelian di bursa seperti halnya saham di pasar modal, bukan di Manajer Investasi (MI). ETF dibagi dua, yaitu ETF index yang menginvestasikan dana yang dikelolanya dalam sekumpulan portofolio efek yang terdapat pada satu indeks tertentu dengan proporsi yang sama dan Close and ETFs, yang terdiri dari dana yang diperdagangkan di bursa efek yang berbentuk perusahaan investasi tertutup dan dikelola secara aktif.

Secara sederhana, yang disebut dengan indeks harga adalah suatu angka yang digunakan untuk membandingkan suatu peristiwa dibandingkan dengan suatu peristiwa lainnya. (Tim BEI, 2009). Angka indeks atau sering disebut dengan indeks saja, pada dasarnya merupakan suatu angka yang dibuat sedemikian rupa sehingga dapat dipergunakan untuk melakukan perbandingan antara kegiatan yang sama dalam 2 waktu yang berbeda (J. Supranto, Statistik, Jakarta: Penerbit Erlangga, 1994). Indeks harga saham adalah indikator perdagangan saham, yang disusun dengan satu formula tertentu yang berlangsung di bursa efek. 
Setiap bursa efek memiliki indeks harga saham yang berbeda-beda. Di New York Stock Exchange (NYSE) dikenal indeks Dow Jones Industrial Average (DJIA) yang berisi 30 jenis saham unggulan. Di BEI kita mengenal beberapa indeks harga saham, di mana indeks yang berisi totalitas saham yang tercatat di bursa disebut dengan IHSG. Selain itu, ada indeks LQ 45 yang berisi 45 jenis saham. Setiap periode tertentu, 45 jenis saham itu akan dievaluasi sehingga komposisinya mengalami perubahan. Ada saham yang keluar dan ada saham yang baru masuk.

Indeks berfungsi sebagai indikator tren pasar, artinya pergerakan indeks menggambarkan kondisi pasar pada suatu saat, apakah pasar sedang aktif atau lesu. Dengan adanya indeks, kita dapat mengetahui tren pergerakan harga saham saat ini, apakah sedang naik, stabil atau turun. Pergerakan indeks menjadi indikator penting bagi para investor untuk menentukan, apakah mereka akan menjual, menahan atau membeli suatu atau beberapa saham. Karena harga-harga saham bergerak dalam hitungan detik dan menit, maka nilai indeks pun bergerak turun naik dalam hitungan waktu yang cepat pula. Demikian juga dengan indeks harga saham, indeks di sini akan membandingkan perubahan harga saham dari waktu ke waktu. Seperti dalam penentuan indeks lainnya, dalam pengukuran indeks harga saham kita memerlukan 2 macam waktu, yaitu waktu dasar dan waktu yang berlaku. Waktu dasar akan dipakai sebagai dasar perbandingan, sedangkan waktu yang berlaku merupakan waktu, di mana kegiatan akan diperbandingan dengan waktu dasar.

Indeks harga saham dibagi menjadi dua, yaitu (1) Indeks harga saham Individu. Indeks harga saham individu hanya menunjukkan perubahan dari suatu harga saham suatu perusahaan. Indeks ini tidak bisa untuk mengukur harga dari suatu saham perusahaan tertentu atau dapat dikatakan bahwa indeks individual saham merupakan suatu nilai yang mempunyai fungsi untuk mengukur kinerja kerja suatu saham tertentu terhadap harga dasarnya; (2) Indeks Harga Saham Gabungan (IHSG). (IHSG) akan menunjukkan pergerakan harga saham secara umum yang tercatat di bursa efek. Indeks inilah yang paling banyak digunakan dan dipakai sebagai acuan tentang perkembangan kegiatan di pasar modal. IHSG ini bisa untuk menilai situasi pasar secara umum atau mengukur, apakah harga saham mengalami kenaikan atau penurunan. Indeks harga ini melibatkan seluruh harga saham yang tercatat bursa.

Metode perhitungan indeks harga saham dibagi menjadi dua cara sebagai berikut. Pertama, Indeks Harga Saham Individu. Seperti sudah dijelaskan pada uraian sebelumnya, untuk menghitung saham, kita memerlukan waktu dasar dan waktu yang berlaku. Harga dasar sering disebut $\mathrm{H}_{\mathrm{o}}$ dan harga yang berlaku sering disebut dengan $\mathrm{H}_{\mathrm{t}}$. Harga dasar ditetapkan sebesar $100 \%$. Secara sederhana rumus untuk menghitung indeks harga saham adalah:

$$
I H S=\frac{H_{t}}{H_{0}} \times 100 \%
$$

Di mana:

$$
\begin{array}{ll}
\text { IHS } & =\text { Indeks harga saham } \\
\mathrm{H}_{\mathrm{t}} & =\text { Harga pada waktu yang berlaku } \\
\mathrm{H}_{0} & =\text { Harga pada waktu dasar }
\end{array}
$$

Pergerakan nilai indeks akan menunjukkan perubahan situasi pasar yang terjadi. Pasar yang sedang bergairah atau terjadi transaksi yang aktif, ditunjukkan dengan indeks harga saham yang mengalami kenaikan, kondisi ini yang biasanya menunjukkan keadaan yang diinginkan. Keadaan stabil ditunjukkan dengan indeks harga saham yang tetap, sedangkan pasar yang lesu ditunjukkan dengan indeks harga saham yang mengalami penurunan.

Waktu dasar merupakan komponen yang penting dalam penentuan indeks harga saham, maka untuk menentukan waktu dasar harus dilakukan dengan benar karena akan dipakai sebagai patokan. 
Waktu dasar dipilih pada saat situasi stabil, pada saat situasi tidak stabil, misalkan pada saat indeks harga tinggi. Untuk penentuan indeks harga selanjutnya hasilnya kurang valid karena akan menunjukkan bahwa indeks harga cenderung terus menerus menurun. Sebaliknya, jika penentuan waktu dasar pada saat pasar sedang lesu, indeks harga akan cenderung menunjukkan peningkatan. Indeks saham individual sangat bermanfaat, khususnya bagi calon investor dalam penentuan jenis saham yang akan dibeli. Indeks saham individual tidak akan berubah jika harga pasar saham tersebut tidak berubah. Hal ini disebabkan karena harga dasar bersifat tetap. Besarnya harga dasar ini akan tetap, sepanjang tidak ada perubahan harga pasar akibat dari harga teoritis baru suatu saham sebagai hasil perhitungan dari pengaruh aksi emiten seperti rights issue, stock split, saham bonus, dividen saham, warrant redeption, dan sebagainya (Robbert Ang, 1997).

Kedua, Indeks Harga Saham Gabungan. Situasi pasar secara umum baru dapat diketahui jika kita mengetahui indeks harga saham gabungan. Untuk perhitungan indeks harga saham gabungan ini, caranya hampir sama dengan menghitung indeks harga saham individual, tetapi harus menjumlahkan seluruh harga saham yang tercatat. Rumus untuk menghitung indeks harga saham gabungan (IHSG) adalah:

$$
I H S G=\frac{\sum H_{t}}{\sum H_{0}} \times 100 \%
$$

Di mana:

IHSG = Indeks harga saham gabungan

$\sum \mathrm{H}_{\mathrm{t}} \quad=$ Total harga semua saham pada waktu yang berlaku

$\sum \mathrm{H}_{0} \quad=$ Total harga semua saham pada waktu dasar

Dari harga indeks inilah kita bisa mengetahui apakah kondisi pasar sedang ramai, lesu atau dalam keadaan stabil. Angka IHSG menunjukkan di atas 100 berarti kondisi pasar sedang ramai, sedangkan pada saat IHSG menunjukkan di bawah 100 berarti kondisi pasar sedang lesu, dan IHSG menunjukkan nilai 100 berarti pasar dalam keadaan stabil.

Dengan semakin terintegrasinya perekonomian global dan menyatunya pasar uang beberapa negara dalam wilayah yang berdekatan, maka ketergantungan ekonomi suatu negara pada ekonomi dunia juga semakin besar, demikian juga yang terjadi dengan pasar modal suatu negara. Nachrowi dan Usman (2006) menjelaskan bahwa pasar modal yang kuat dapat mempengaruhi pasar modal yang lemah. Sebagai salah satu pasar modal yang sedang berkembang, BEI diduga sangat dipengaruhi indeks pasar saham dunia yang berkapitalisasi besar, yaitu Dow Jones Industrial Average (DJIA) dari bursa saham New York, Nikkei 225 (bursa saham Tokyo), KOSPI (bursa saham Korea), dan SSE (bursa saham Shanghai). Indeks dari keempat bursa itu dapat digunakan sebagai variabel independen yang menentukan pergerakan IHSG.

Walaupun peranan investor domestik makin meningkat, akan tetapi terdapat kebiasaan dari investor domestik untuk melakukan strategi mengekor pada investor asing atau setidaknya investor domestik menggunakan perilaku investor asing sebagai acuan (Cahyono, 2000: 93). Berdasarkan uraian pada kerangka teoritis tentang beberapa indeks bursa global yang mempengaruhi IHSG BEI, maka hipotesis yang akan diuji dalam penelitian ini dapat dirumuskan sebagai berikut:

$\mathrm{H}_{1}$ : Terdapat pengaruh indeks Dow Jones terhadap IHSG BEI

$\mathrm{H}_{2}$ : Terdapat pengaruh indeks Nikkei 225 terhadap IHSG BEI

$\mathrm{H}_{3}$ : Terdapat pengaruh indeks KOSPI terhadap IHSG BEI

$\mathrm{H}_{4}$ : Terdapat pengaruh indeks SSE terhadap IHSG BEI 
Sedangkan model penelitian dapat dilihat pada gambar berikut (Gambar 1).

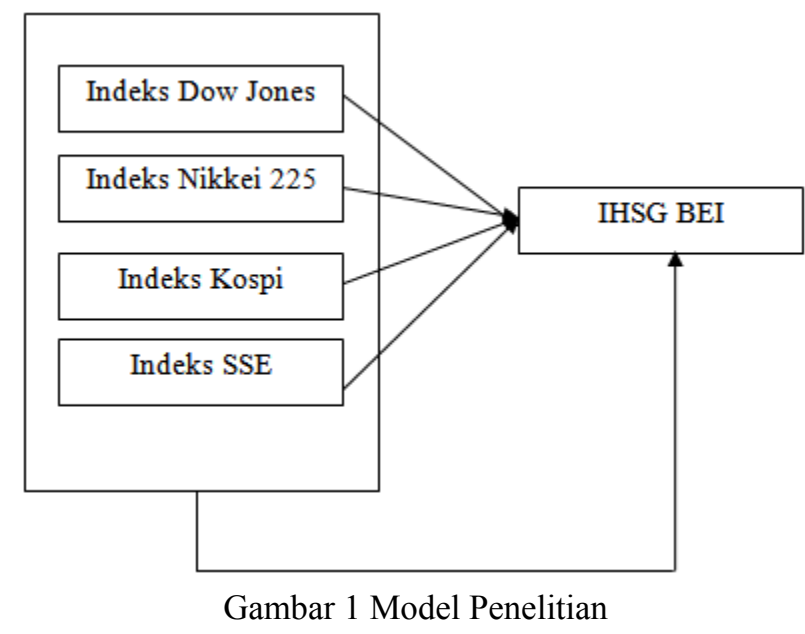

METODE PENELITIAN

\section{Pengumpulan Data dan Pemilihan Sampel}

Metode penelitian bersifat ex post-facto, yaitu pengumpulan data dilakukan setelah semua kejadian selesai berlangsung. Pengambilan sampel dilakukan dengan non probability random sampling dengan metode purposive sampling. Sampel yang diambil adalah indeks penutupan mingguan selama 5 tahun terakhir, yaitu tahun 2004 sampai dengan 2008, untuk Indeks Dow Jones, Indeks Nikkei 225, Indeks KOSPI, Shanghai Composite Index dan IHSG BEI. Berdasarkan kriteria tersebut, maka diperoleh 170 sampel yang dapat mewakili populasi dan memenuhi syarat.

\section{Operasionalisasi Variabel-variabel Penelitian}

Variabel-variabel yang digunakan dalam penelitian ini berjumlah 7, yaitu (1) Indeks Dow Jones. Menggunakan metode price weighted, di mana Dow Jones adalah indeks utama pada bursa saham New York dan perhitungannya menggunakan sampel seluruh saham yang listing di bursa saham NYSE; (2) Indeks Nikkei 225. Indeks ini memakai metode price weighted, di mana sahamsaham yang menjadi sampel pada perhitungan indeks ini terdiri dari 225 perusahaan ranking tertinggi pada sesi pertama di bursa saham Tokyo. Indeks ini diperkenalkan pada tanggal 16 Mei 1949, dengan harga rata-rata 176,21 dan dengan pembagi 225; (3) Indeks KOSPI. Perhitungannya memakai metode value weighted. Indeks ini menggunakan sampel seluruh saham yang tercatat di bursa saham Korea. Indeks ini dihitung berdasarkan nilai dasar pada tanggal 4 Januari 1980; (4) Indeks SSE. Indeks SSE menggunakan metode value weighted, di mana indeks ini dihitung dari hasil perkalian total kapitalisasi pasar seluruh saham di bursa Shanghai pada hari yang bersangkutan dengan nilai dasar yang telah ditetapkan, yaitu 100 serta dibagi dengan nilai dasar pada periode dasar, yaitu 19 Desember 1990; dan (5) IHSG BEI. IHSG BEI dihitung dengan menggunakan metode value weighted berdasarkan kapitalisasi pasar. Perhitungan IHSG mencakup seluruh saham yang listing di BEI. Tahun dasar IHSG adalah 10 Agustus 1982.

\section{Analisis Data}

Analisis data yang digunakan dalam penelitian ini adalah analisis regresi berganda (multiple regression). Alasan penulis memilih metode analisis regresi berganda di dalam penelitian ini karena 
penulis ingin mengetahui pengaruh antara beberapa variabel independen (Indeks Dow Jones, Nikkei 225, KOSPI, dan SSE) terhadap variabel dependen (IHSG). Adapun bentuk persamaan regresi berganda yang akan digunakan adalah sebagai berikut:

Di mana:

$$
\text { IHSG }=a+b_{1} \text { DowJones }+b_{2} \text { Nikkei }+b_{3} \text { Kospi }+b_{4} \text { SSE }+e
$$

IHSG = Indeks Harga Saham Gabungan Bursa Efek Indonesia

DowJones $\quad=$ Indeks Dow Jones

Nikkei $\quad=$ Indeks Nikkei 225

KOSPI $\quad=$ Indeks KOSPI

SSE $\quad=$ Indeks SSE

Metode estimasi yang digunakan dalam penelitian ini adalah Ordinary Least Square (OLS). Hasil estimasi yang menggunakan metode OLS diharapkan bersifat Best Linear Unbiased Estimate (BLUE). Untuk itu model yang dibuat harus memenuhi beberapa asumsi dasar OLS, yaitu tidak ada hubungan erat antar variabel bebas (multikolinearitas), nilai varians dari residual adalah sama (homoskedastisitas), tidak terjadi autokorelasi, dan data residual bersifat normal.

\section{HASIL DAN PEMBAHASAN}

Tabel 1 Statistik Deskriptif

\begin{tabular}{lccccc}
\hline \multicolumn{1}{c}{ Variabel } & n & Minimum & Maximum & Mean & $\begin{array}{c}\text { Deviasi } \\
\text { Standar }\end{array}$ \\
\hline IHSG BEI & 170 & 1028.98 & 2830.26 & 1764.54671 & 540.474716 \\
Indeks Dow Jones & 170 & 6626.94 & 14066 & 11035.4568 & 1675.37742 \\
Indeks Nikkei 225 & 170 & 7173.1 & 18239 & 13402.5582 & 3065.10592 \\
Indeks KOSPI & 170 & 911.3 & 2028.06 & 1424.42394 & 279.6463 \\
Indeks SSE & 170 & 1026.12 & 5777.81 & 2576.09665 & 1261.79825 \\
\hline
\end{tabular}

Tabel 2 Hasil Estimasi Regresi

\begin{tabular}{|c|c|c|c|c|c|c|}
\hline Variabel & B & Std. Error & $\mathbf{t}$ & Sig. & Tolerance & VIF \\
\hline Konstanta & -311.289 & 117.344 & -2.653 & 0.009 & & \\
\hline Indeks Dow Jones & 0.057 & 0.019 & 3.033 & 0.003 & 0.154 & 6.481 \\
\hline Indeks Nikkei 225 & -0.070 & 0.009 & -7.498 & 0.000 & 0.185 & 5.413 \\
\hline Indeks KOSPI & 1.519 & 0.103 & 14.692 & 0.000 & 0.181 & 5.528 \\
\hline Indeks SSE & 0.087 & 0.023 & 3.829 & 0.000 & 0.182 & 5.493 \\
\hline $\mathrm{R}$ & 0,956 & & & & & \\
\hline R Square & 0,915 & & & & & \\
\hline Adj. R Square & 0,913 & & & & & \\
\hline F Statistik & 441,842 & & & & & \\
\hline $\operatorname{Sig}(F)$ & 0,000 & & & & & \\
\hline Durbin Watson & 0,287 & & & & & \\
\hline Asymp. Sig. (K-S) & 0,669 & & & & & \\
\hline
\end{tabular}




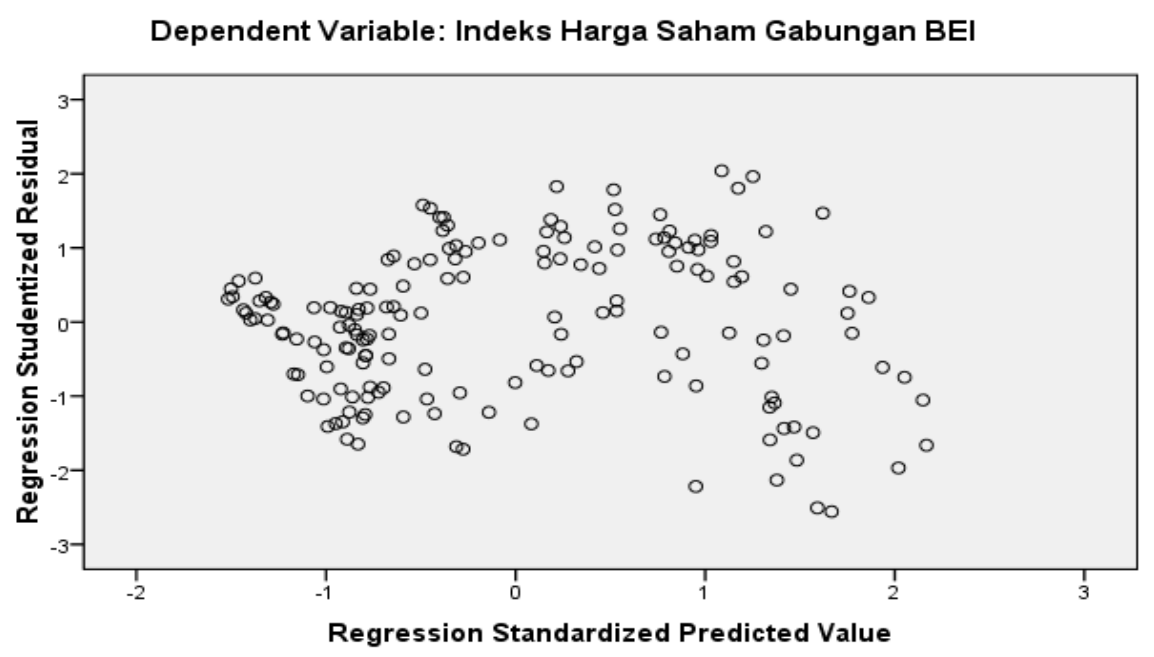

Gambar 2 Hasil Uji Homoskedastisitas

Sebelum pengujian hipotesis dilakukan, maka terlebih dahulu dilakukan uji asumsi klasik yang terdiri dari multikolinearitas, homoskedastisitas, autokorelasi, dan normalitas. Nilai tolerance yang lebih dari 0,1 dan VIF yang kurang dari 10 menunjukkan bahwa tidak terjadi masalah multikolinearitas. Nilai Durbin Watson sebesar 0,287 yang lebih kecil dari nilai $d_{L}$ sebesar 1,728 menunjukkan bahwa terdapat autokorelasi positif. Hasil scatter plot menunjukkan bahwa titik-titik yang menyebar dan tidak membentuk pola tertentu dalam scatter plot tersebut sehingga dapat disimpulkan bahwa asumsi homoskedastisitas terpenuhi atau tidak terjadi problem heterosledastisitas. Pengujian normalitas dengan One Sample Kolmogorov Smirnov Test menunjukkan hasil sig. sebesar 0,669. Nilai sig. yang lebih besar dari tingkat signifikansi 0,05 menunjukkan bahwa asumsi normalitas residual terpenuhi. Dari hasil uji asumsi klasik di atas, diketahui bahwa asumsi autokorelasi tidak terpenuhi. Hal ini disebabkan data penelitian berurutan sepanjang waktu atau time series sehingga terjadi gangguan dari satu observasi ke observasi lainnya. Dengan adanya perpanjangan periode penelitian, dibandingkan dengan penelitian sebelumnya, diharapkan problem tersebut hilang. Akan tetapi, problem autokorelasi tersebut tetap terjadi, dan selanjutnya dalam penelitian ini asumsi autokorelasi dalam model penelitian diabaikan, dengan harapan penelitian ini dapat memberikan hasil yang terbaru. Hasil uji asumsi multikolinieritas, homoskedastisitas dan normalitas tersebut juga menyatakan bahwa ketiga asumsi tersebut terpenuhi sehingga dari hasil tersebut model regresi ganda yang dihasilkan diasumsikan memenuhi syarat BLUE.

Hasil Uji-F menunjukkan sig. sebesar 0,000. Hal tersebut menunjukkan bahwa variabel independen (Indeks Dow Jones, Nikkei 225, KOSPI, dan SSE) secara bersama-sama mempunyai pengaruh terhadap variabel dependen (IHSG). Berdasarkan hasil Uji-F tersebut, dengan demikian uji secara parsial (uji-t) untuk menjawab hipotesis penelitian dapat dilakukan sehingga diketahui variabel independen mana saja yang mempengaruhi harga saham.

Hasil Uji-t menunjukkan nilai sig. untuk Indeks Dow Jones sebesar 0,003. Nilai sig. tersebut kurang dari 0,05 sehingga dapat disimpulkan bahwa hipotesis pertama $\left(\mathrm{H}_{1}\right)$ dapat diterima, di mana terdapat pengaruh Indeks Dow Jones terhadap IHSG. Penelitian ini mendukung penelitan Indra Kusuma (2008) yang menunjukkan bahwa Indeks Dow Jones berpengaruh signifikan terhadap IHSG, tetapi tidak konsisten dengan penelitian Moh.Mansur (2005) yang menyatakan bahwa secara individual, Indeks Dow Jones tidak mempunyai pengaruh terhadap IHSG. Nilai sig. untuk Indeks 
Nikkei 225 sebesar 0,000 menunjukkan nilai yang lebih kecil dari 0,05. Dari hasil tersebut, dapat disimpulkan bahwa hipotesis kedua $\left(\mathrm{H}_{2}\right)$ dapat diterima, di mana terdapat pengaruh yang signifikan Indeks Nikkei 225 terhadap IHSG. Hasil penelitian ini konsisten dengan penelitian Moh.Mansur (2005) yang menyatakan bahwa secara individual Indeks Nikkei 225 mempengaruhi IHSG. Nilai sig. Indeks KOSPI yang sebesar 0,000 juga lebih kecil dari 0,05 , di mana hal ini menunjukkan bahwa hipotesis ketiga dapat diterima sehingga terdapat pengaruh Indeks KOSPI terhadap IHSG. Hasil ini mendukung penelitian Moh.Mansur (2005) yang menyatakan bahwa Indeks KOSPI secara individual mempengaruhi IHSG. Hasil sig. Indeks SSE sebesar 0,000 juga menunjukkan nilai yang lebih kecil dari 0,005 sehingga dapat disimpulkan hipotesis keempat juga dapat diterima, di mana terdapat pengaruh Indeks SSE terhadap IHSG. Hasil ini mendukung pernyataan Anggarini Lubis (2009) dalam artikelnya yang menyatakan bahwa Indeks Shanghai memberikan pengaruh besar pada Indeks Harga Saham Gabungan (IHSG).

\section{SIMPULAN}

Berdasarkan hasil penelitian dan pembahasan yang telah dikemukakan, maka dapat disimpulkan bahwa Indeks Dow Jones, Nikkei 225, KOSPI, dan SSE, baik secara simultan maupun parsial mempunyai pengaruh yang signifikan terhadap IHSG BEI. Penelitian ini mendukung penelitian yang dilakukan oleh Moh.Mansur (2005) tentang pengaruh Indeks Bursa Global terhadap Indeks Harga Saham Gabungan pada Bursa Efek Jakarta tahun 2000 sampai 2002, di mana hasilnya adalah Indeks Nikkei 225 dan Indeks KOSPI mempunyai pengaruh signifikan terhadap IHSG BEI. Penelitian ini juga mendukung penelitian yang dilakukan oleh Indra Kusuma yang menyatakan bahwa Dow Jones berpengaruh signifikan terhadap IHSG serta mendukung artikel Anggraini Lubis (2009) yang mengemukakan bahwa Indeks Shanghai berpengaruh terhadap IHSG.

Keterbatasan penelitian ini adalah (1) Penelitian yang dilakukan hanya mencakup 4 variabel independen, yaitu Indeks Dow Jones, Nikkei 225, KOSPI, dan SSE sehingga tidak mencerminkan reaksi IHSG di pasar modal dunia secara keseluruhan; (2) Penelitian yang dilakukan hanya menggunakan 5 tahun penelitian, yaitu dari tahun 2004 sampai 2008. Dari beberapa keterbatasan yang dikemukakan tersebut, hasil penelitian ini diharapkan dapat mendorong penelitian-penelitian berikutnya. Para peneliti dapat melanjutkan penelitian ini dengan mempertimbangkan beberapa faktor seperti (1) Menambah variabel independen dengan indeks bursa global lainnya, dan (2) Jumlah periode pengamatan penelitian diperluas agar sampel yang diperoleh lebih banyak dan dimungkinkan masalah autokorelasi dapat teratasi.

\section{DAFTAR PUSTAKA}

Ang, R. (1997). Buku pintar pasar modal Indonesia, MediaSoft Indonesia.

Cahyono, Jaka E (2000). 22 strategi dan teknik meraih untung di bursa saham. jilid 1. Jakarta: Elex Media Komputindo

Darmadi, T., dan Fakhruddin, HM (2001). Pasar modal di Indonesia: pendekatan tanya jawab. Jakarta: Salemba Empat. 
Kusuma, I. (2008). Dampak perubahan indeks saham Dow Jones di New York stock exchange dan harga minyak dunia terhadap pergerakan indeks harga saham gabungan di bursa efek Indonesia.

Lubis, Anggraini (2009). BUMI sokong IHSG pagi naik 25 poin, waspada online. Diambil dari Http://www.waspada.co.id/index.php?option=com_content\&view=article\&id=46138:saham_i ndeks shanghai_seret_ihsg_ke_zona_negatif\&catid $=18 \&$ itemid $=95$.

Mansur, M. (2005). Pengaruh indeks bursa global terhadap indeks harga saham gabungan (ihsg) pada bursa efek Jakarta periode tahun 2000-2002, Bandung: Universitas Padjajaran.

Nachrowi, Nachrowi D. dan Hardius Usman (2006). Ekonometrika untuk analisis ekonomi dan keuangan-pendekatan populer dan praktis. Jakarta: LPFE UI.

Supranto, J. (1994). Statistik: Teori dan aplikasi, Jakarta: Erlangga.

Tim BEI. Memahami indeks harga saham. H.U Menado Post, edisi 1 April 2009. 